\title{
Synthesis of Gaseous Hydrocarbons from Carbon Monoxide and Hydrogen over Transition Metal Catalysts (Part 3)
}

\author{
Deactivation and Reaction Characteristics on Iron \\ Lamellar Compounds of Graphite Catalysts
}

\author{
Eiichi Kikughi*, Mitsugu Yumoto*, Yasuhiko Aranishi* \\ and Yoshiro Morita*
}

\begin{abstract}
Characteristic behavior of an iron-graphite lamellar complex catalyst in hydrocarbon synthesis was investigated in a flow system. It was found that steam formed during the synthesis affected the activities and distribution of the hydrocarbons on this catalyst. At low $\mathrm{GO}$ conversion levels with small quantities of coexistent steam, the catalytic activity decreased with time on stream, accompanied with a shift of hydrocarbon distribution towards methane. The addition of steam to the reactant gas prevented catalyst deactivation, and higher molecular weight hydrocarbons were produced in greater proportions. The high sensitivity of this catalyst to steam was attributed to its low density of the active sites in comparison with those of the conventional iron catalysts.
\end{abstract}

\section{Introduction}

Hydrogenation of carbon monoxide has been studied using several supported and unsupported iron catalysts ${ }^{1)}$. Among the catalysts tested, graphite-supported catalysts were the most selective for the production of $\mathrm{C}_{2} \sim \mathrm{C}_{4}$ olefinic hydrocarbons. Such effect of graphite, as carrier, was enhanced by intercalating $\mathrm{Fe}$ between graphite layers ${ }^{2)}$. Another characteristic behavior of the Fe-LCG (lamellar compound of graphite) is attributed with its high selectivity for higher hydrocarbon production, suppressing carbon dioxide production.

In a previous paper ${ }^{2)}$, it was also shown that distribution of product hydrocarbons was sensitive to the degree of $\mathrm{CO}$ conversion. At lower levels of $\mathrm{CO}$ conversion, methane was predominantly formed and the selectivity for the formation of $\mathrm{C}_{2} \sim \mathrm{C}_{4}$ hydrocarbons increased with increasing $\mathrm{CO}$ conversion. A similar phenomenon has recently been reported by Dwyer and Somorjai ${ }^{3)}$ whose polycrystalline $\mathrm{Fe}$ foil catalyst also yields methane primarily at conversion levels less than $1 \%$. According to their results obtained in a closed reactor system, the addition of ethylene and propylene to the reaction system resulted in the production of

\footnotetext{
Received October 5, 1979.

* Department of Applied Chemistry, School of Science and Engineering, Waseda University (3-4-1, Okubo, Shinjuku-ku, Tokyo 160)
}

higher molecular weight hydrocarbons in larger amounts. Thus, they have suggested that readsorption and secondary reaction of the initially produced $\alpha$-olefins are important steps leading to the formation of large molecular weight hydrocarbons. This explanation, however, can hardly account for the variation of hydrocarbon distribution with $\mathrm{CO}$ conversion observed for the Fe-LCG catalyst in a flow reactor system, since the addition of ethylene to the reactant mixture changed only slightly the distribution of hydrocarbons on this catalyst.

In this paper, we attempt to verify the effect of steam produced during the course of $\mathrm{CO}-\mathrm{H}_{2}$ conversion on the product distribution, particularly on enhancement of higher molecular weight hydrocarbon production.

\section{Experimental}

\subsection{Materials}

The method of catalyst preparation was described in detail previously2). An LGG of $\mathrm{FeCl}_{3}$ was prepared from a mixture of graphite and anhydrous $\mathrm{FeCl}_{3}$ in the ratio of 10:11 by weight. The resulting $\mathrm{FeCl}_{3}-\mathrm{LCG}$ contained $44 \% \mathrm{FeCl}_{3}$ by weight. Prior to use as catalyst, this LCG was reduced at $400^{\circ} \mathrm{C}$ for $7 \mathrm{hr}$ in a stream of hydrogen, and washed with an aqueous solution of $\mathrm{HCl}$ to remove trace amounts of $\mathrm{Fe}$ eluted from graphite layers. Commercial $\mathrm{CO}$ and $\mathrm{H}_{2}$, premixed in the molar ratio of $1: 1 \sim 1: 3$, were used in the catalytic study 
after removing the iron carbonyl impurity in an activated charcoal column.

\subsection{Apparatus and Procedure}

The catalytic reaction was carried out in a flow system at $400^{\circ} \mathrm{C}$ and $10 \sim 30$ atm using the same reactor described previously ${ }^{2}$. The time factor was defined by $\mathrm{W} / \mathrm{F}$, where $\mathrm{W}$ and $\mathrm{F}$ are catalyst weight ( $\mathrm{g}$ ) and the feed rate of $\mathrm{CO}(\mathrm{mol} / \mathrm{min})$, respectively. The effluent gases from the reactor were monitored with a gas meter and their compositions were determined by means of gas chromatography.

\section{Results and Discussion}

Typical variation in catalytic activity and distribution of product hydrocarbons with time on stream are shown in Figs. 1 and 2. Here the activity is expressed in terms of $X_{\mathrm{HC}}$ which means percentage of $\mathrm{CO}$ converted to hydrocarbons:

$$
X_{\mathrm{HC}}=\frac{\sum i\left(\mathrm{C}_{i}\right)}{(\mathrm{CO})+\left(\mathrm{CO}_{2}\right)+\sum i\left(\mathrm{G}_{i}\right)} \times 100
$$

Here $\left(\mathrm{C}_{i}\right)$ is the molar concentration of the hydrocarbon whose carbon number is $i$, and ( $\mathrm{CO}$ ) and $\left(\mathrm{CO}_{2}\right)$ are those of $\mathrm{CO}$ and $\mathrm{CO}_{2}$, respectively. Under the reaction conditions studied, the formation of $\mathrm{CO}_{2}$ was small and the selectivity for hydrocarbon production, expressed by $\mathrm{S}=X_{\mathrm{HC}} / X(X$ is total conversion of $\mathrm{CO}$ ), was higher than $95 \%$, as typically shown in Table $\mathbf{1}$.

At $\mathrm{W} / \mathrm{F}=102$ or low $\mathrm{CO}$ conversion (less than $5 \%$ ) as shown in Fig. 1, the catalytic activity gradually decreased with time on stream and finally reached a steady state. With the decrease in catalytic activity, the distribution of product hydrocarbons shifted to methane. On the other hand, at $\mathrm{W} / \mathrm{F}=522$ or at higher conversion levels (around $17 \%$ ), both catalytic activity and hydrocarbon distribution scarcely changed with time on stream as

\section{shown in Fig. 2.}

The most remarkable difference in the constituents of the reaction mixture between these two experiments is the amount of steam produced during the hydrocarbon synthesis. Then the effect of addition of steam to the reaction system was examined

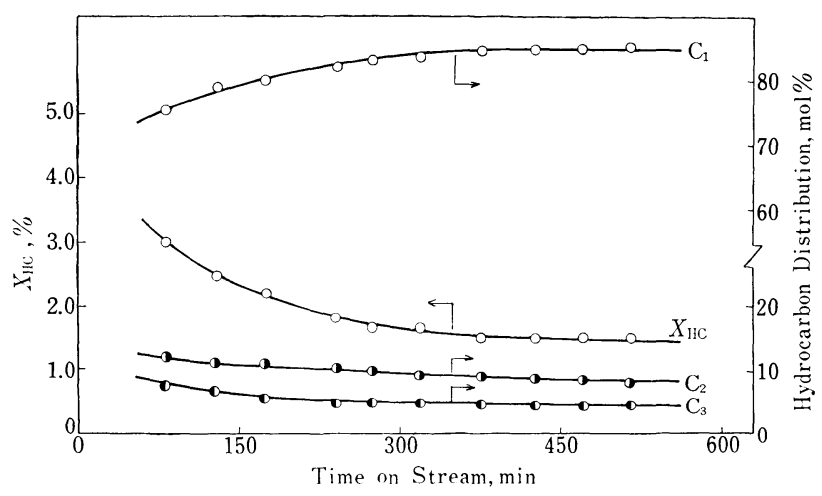

Reaction conditions :

Temperature $=400^{\circ} \mathrm{C}, \quad$ Pressure $=20 \mathrm{~atm}$

Fig. 1 Variation in $X_{\mathrm{HC}}$ and Hydrocarbon Distribution with Time on Stream at $\mathrm{W} / \mathrm{F}=102 \mathrm{~g}-\mathrm{cat} \cdot \mathrm{min} /$ $\mathrm{CO}-\mathrm{mol}$

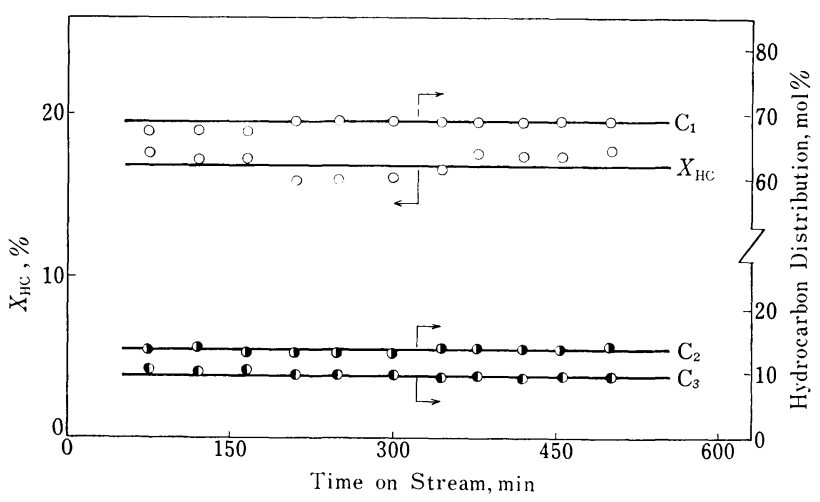

Reaction conditions :

Temperature $=400^{\circ} \mathrm{C}, \quad$ Pressure $=20 \mathrm{~atm}$

Fig. 2 Variation in $X_{\mathrm{HC}}$ and Hydrocarbon Distribution with Time on Stream at $\mathrm{W} / \mathrm{F}=522 \mathrm{~g}-\mathrm{cat} \cdot \mathrm{min} /$ CO-mol

Table 1 Gatalytic Selectivity and Distribution of Product Hydrocarbons

\begin{tabular}{|c|c|c|c|c|c|c|c|c|}
\hline \multirow{2}{*}{$\begin{array}{l}\mathrm{W} / \mathrm{F} \text { (g-cat. } \\
\mathrm{min} / \mathrm{CO}-\mathrm{mol})\end{array}$} & \multirow{2}{*}{$X_{\mathrm{HC}}(\%)$} & \multirow{2}{*}{$\mathrm{S}(\%)$} & \multicolumn{6}{|c|}{ Hydrocarbon Distribution (mol\%) } \\
\hline & & & $\mathrm{C}_{1}$ & $\mathrm{C}_{2}$ & $\mathrm{C}_{3}$ & $\mathrm{C}_{4}$ & $\mathrm{C}_{5}$ & $\mathrm{C}_{6}$ \\
\hline 102 & 1.3 & 100 & 92.5 & $\begin{array}{l}4.2 \\
(0.76\end{array}$ & $\begin{array}{c}2.1 \\
(1.0)\end{array}$ & 0.7 & 0.5 & - \\
\hline 198 & 3.7 & 100 & 86.4 & $\begin{array}{l}6.3 \\
(0.72)\end{array}$ & $\begin{array}{c}4.5 \\
(1.0)\end{array}$ & 1.9 & 0.9 & - \\
\hline 280 & 8.1 & 100 & 74.8 & $\begin{array}{l}12.1 \\
(0.68)\end{array}$ & $\begin{array}{c}8.2 \\
(1.0)\end{array}$ & 3.1 & 1.8 & - \\
\hline 450 & 15.8 & 100 & 69.7 & $\begin{array}{l}13.3 \\
(0.62)\end{array}$ & $\begin{array}{c}9.9 \\
(1.0)\end{array}$ & 4.6 & 2.4 & - \\
\hline $102 *$ & 4.1 & 100 & 71.9 & $\begin{array}{l}11.1 \\
(0.46)\end{array}$ & $\begin{array}{c}8.4 \\
(1.0)\end{array}$ & 3.6 & 2.9 & 2.3 \\
\hline 198* & 12.5 & 98 & 63.5 & $\begin{array}{l}14.5 \\
(0.42)\end{array}$ & $\begin{array}{l}10.5 \\
(1.0)\end{array}$ & 4.6 & 3.7 & 3.2 \\
\hline
\end{tabular}

*) in the presence of steam $(2.2 \mathrm{~atm})$ 


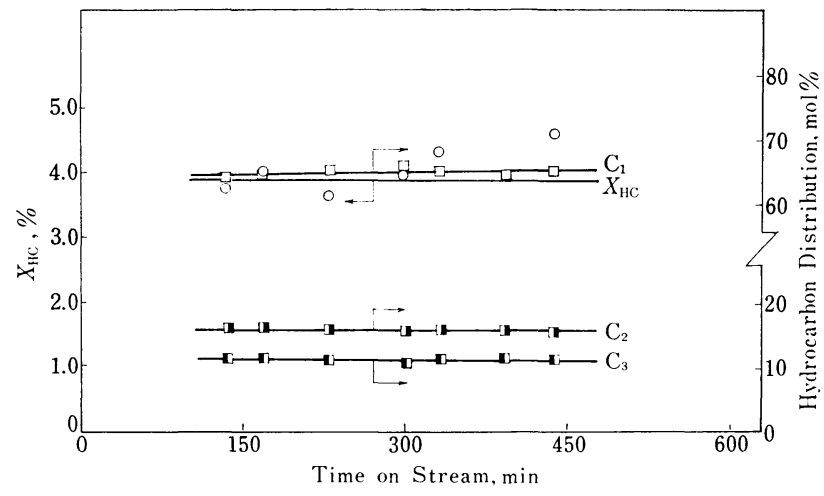

Reaction conditions :

Temperature $=400^{\circ} \mathrm{C}, \quad \mathrm{P}_{\mathrm{CO}+\mathrm{H}_{2}}=20 \mathrm{~atm}$

$\mathrm{P}_{\mathrm{H}_{2} \mathrm{O}}=2.2 \mathrm{~atm}, \mathrm{~W} / \mathrm{F}=102 \mathrm{~g}$-cat $\cdot \mathrm{min} / \mathrm{CO}-\mathrm{mol}$

Fig. 3 Effect of the Addition of Steam on the Variation in $X_{\mathrm{HC}}$ and Hydrocarbon Distribution with Time on Stream

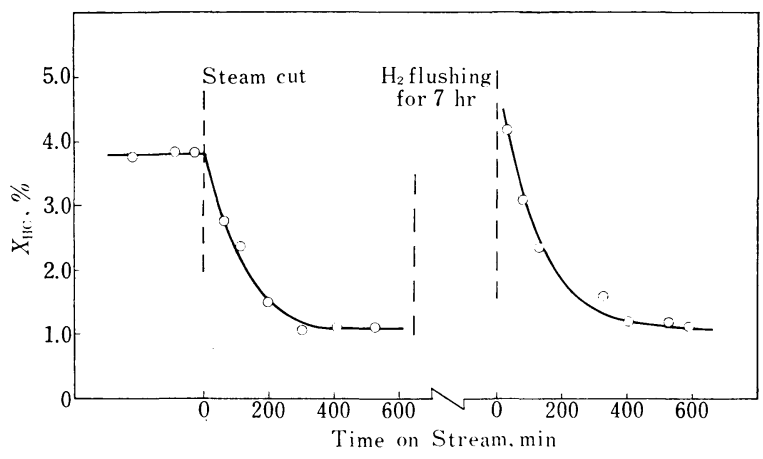

Reaction conditions :

Temperature $=400^{\circ} \mathrm{C}, \quad \mathrm{P}_{\mathrm{CO}+\mathrm{H}_{2}}=20 \mathrm{~atm}$

$\mathrm{P}_{\mathrm{H}_{2} \mathrm{O}}=2.2 \mathrm{~atm}, \mathrm{~W} / \mathrm{F}=102 \mathrm{~g}-\mathrm{cat} \cdot \mathrm{min} / \mathrm{CO}-\mathrm{mol}$

$\mathrm{P}_{\mathrm{H}_{2}}$ at $\mathrm{H}_{2}$ flushing $=13.4 \mathrm{~atm}$

Fig. 4 Effect of Hydrogen Flushing on the Regeneration of Catalytic Activity

at $\mathrm{W} / \mathrm{F}=102$. Fig. 3 shows a typical experimental result where $2.2 \mathrm{~atm}$ of steam was fed together with $\mathrm{CO}$ and $\mathrm{H}_{2}$. The coexistence of steam did not result in the formation of oxygenated compound but it slightly enhanced the formation of $\mathrm{CO}_{2}$ as shown by the decrease in $\mathrm{S}(\%)$ in Table 1. By comparison between the results shown in Figs. $\mathbf{1}$ and 3, there were two important observations by addition of steam: (i) The initial catalytic activity retained its stationary value. (ii) The distribution of product hydrocarbons shifted towards higher molecular weight hydrocarbons.

Following the experiment shown in Fig. 3, the feeding of steam was discontinued. As shown in Fig. 4, the catalytic activity abruptly decayed and the resulting activity could be completely restored by subsequent treatment in $\mathrm{H}_{2}$ atmosphere. During the above treatment, the formation of methane

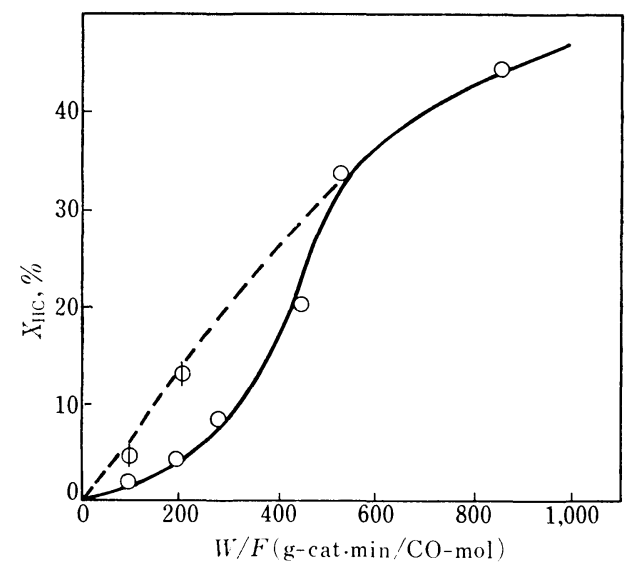

0 : without the addition of steam. $\Phi$ : with the addition of steam $\left(\mathrm{P}_{\mathrm{H}_{2} \mathrm{O}}=2.2 \mathrm{~atm}\right)$ Reaction conditions :

Temperature $=400^{\circ} \mathrm{C}, \quad \mathrm{P}_{\mathrm{H}_{2}+\mathrm{CO}}=20 \mathrm{~atm}$

Fig. 5 Effect of Time Factor (W/F) on the Extent of $\mathrm{CO}$ Conversion to Hydrocarbons $\left(X_{\mathrm{HC}}\right)$

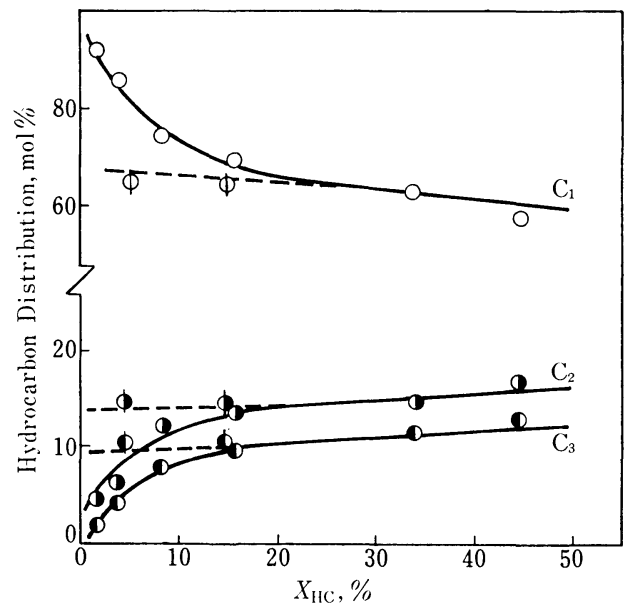

$\bigcirc$ : without the addition of steam

$\phi \phi$ : with the addition of steam $\left(\mathrm{P}_{\mathrm{H}_{2} \mathrm{O}}=2.2 \mathrm{~atm}\right)$

Fig. 6 Variation in Hydrocarbon Distribution with the Extent of CO Conversion

continued for about $400 \mathrm{~min}$. Consequently, the carbon deposition on the active sites seemed to be related with the catalyst deactivation.

The effect of time factor $\mathrm{W} / \mathrm{F}$ on $\mathrm{CO}$ conversion to hydrocarbons was investigated with and without the addition of steam. A typical result is shown in Fig. 5, where steady state values of $X_{\mathrm{HC}}$ are plotted against $\mathrm{W} / \mathrm{F}$. The catalytic selectivity and hydrocarbon distribution observed are given in Table 1 and Fig. 6.

In the case of $\mathrm{CO}$ hydrogenation, without the addition of steam, an S-shape conversion vs. time factor curve was obtained. On the other hand, a smooth curve (dotted line in Fig. 5) between $X_{\mathrm{HC}}$ and $\mathrm{W} / \mathrm{F}$ was obtained for the reaction with 
the addition of steam where no catalyst deactivation took place. The hydrocarbon distribution in the absence of steam, deviated with decreasing $X_{\mathrm{HC}}$ from that in the presence of initially added steam. At higher conversion levels, they overlapped and slightly shifted towards higher molecular weight hydrocarbons. The result may be due to readsorption and secondary reaction of initially produced olefins as described by Dwyer and Somorjai ${ }^{3)}$.

The initial rates of hydrocarbon synthesis were determined both in the absence and presence of steam at low conversion levels (less than $5 \%$ )

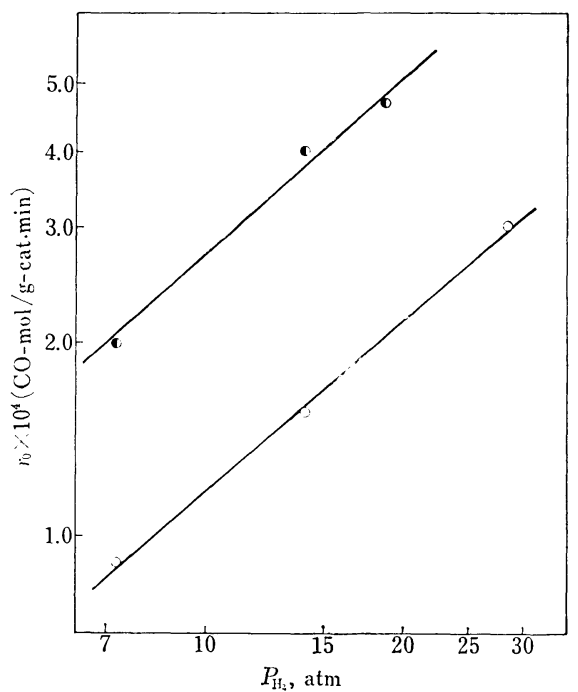

$\mathrm{O}$ : without the addition of steam

(1) : with the addition of steam $\left(\mathrm{P}_{\mathrm{H}_{2} \mathrm{O}}=2.2 \mathrm{~atm}\right)$. Reaction conditions :

Temperature $=400^{\circ} \mathrm{C}, \quad \mathrm{P}_{\mathrm{CO}}=6.6 \mathrm{~atm}$

Fig. 7 Relation between Initial Rate and Partial Pressure of Hydrogen

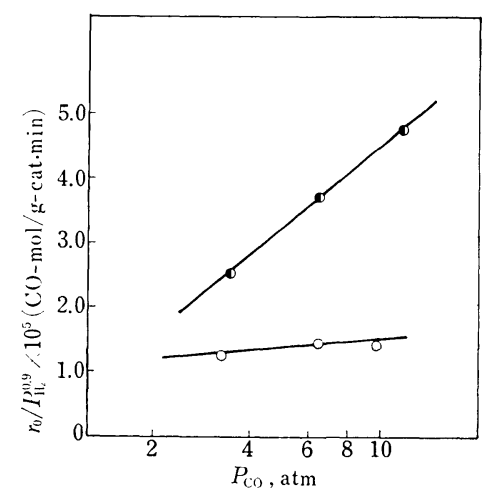

$O$ : without the addition of steam

: with the addition of steam $\left(\mathrm{P}_{\mathrm{H}_{2} \mathrm{O}}=2.2 \mathrm{~atm}\right)$

Reaction conditions :

Temperature $=400^{\circ} \mathrm{C} ; \mathrm{H}_{2} / \mathrm{CO}=2.1 \mathrm{~mol} / \mathrm{mol}$

Fig. 8 Relation between Initial Rate and Partial Pressure of Carbon Monoxide according to the following relation:

$$
r_{0}=\frac{X_{\mathrm{HC}}}{100} \cdot \frac{\mathrm{F}}{\mathrm{W}}
$$

The partial pressure of added steam was adjusted to $P_{\mathrm{H}_{2} \mathrm{O}} / P_{\mathrm{CO}}=0.33$, as no catalyst deactivation took place at this ratio. The initial rate increased with increasing partial pressure of hydrogen as shown in Fig. 7. The reaction order with respect to hydrogen was determined as 0.9 for either case. In the presence of steam, the initial rate increased with the partial pressure of $\mathrm{CO}$ in the reaction order of 0.47 . In the absence of steam, however, the apparent reaction order with respect to $\mathrm{CO}$ was about 0.05 , probably due to the catalyst deactivation enhanced by the increase in the partial pressure of $\mathrm{CO}$ (Fig. 8).

These results obtained seem to give a comprehensive explanation for the variation in product hydrocarbon distribution, which is highly sensitive to the degree of $\mathrm{CO}$ conversion. At low levels of $\mathrm{CO}$ conversion, low concentrations of product steam in the reaction mixture cause deactivation of $\mathrm{Fe}$ active sites through carbon deposition. As synthesis of higher molecular weight hydrocarbons must be accompanied by chain propagation of the surface species, adjacent active sites should be required for the formation of hydrocarbons other than methane. Thus, blocking of adjacent active sites with deposited carbon causes hydrocarbon distribution to shift towards methane. As CO conversion increases, the concentration of product steam also increases and catalyst deactivation is avoided, resulting in the product distribution with higher molecular weight hydrocarbons in larger proportions.

The requirement of adjacent active sites for synthesis of higher molecular weight hydrocarbons is in agreement with the mechanisms proposed for this reaction on Fe catalysts ${ }^{4}$. Extraordinally high sensitivity of hydrocarbon distribution against $\mathrm{CO}$ conversion on the Fe LCG catalyst, in contrast to the conventional Fe catalysts, may be due to the inherently low concentration of active sites on the Fe LCG catalyst.

\section{References}

1) Kikuchi, E., Ino, T., Ito, N., Morita, Y., J. Japan Petrol. Inst., 21, (4), 242 (1978).

2) Kikuchi, E., Ino, T., Morita, Y., J. Catal., 57, 27 (1979).

3) Dwyer, D. J., Somorjai, G. A., J. Catal., 56, 249 (1979).

4) Arai, H., Yukagaku, 27, ( 8), 491;27, (9), 572 (1978). 
要 旨

\section{遷移金属触媒上での一酸化岸素と水素による気体炭化水素の合成（第 3 報）}

\section{鉄グラファイト層間化合物触媒の活性低下と反応特性}

菊地 英一, 湯本 貢*, 荒西 康彦*, 森田 義郎*

$\mathrm{C}_{2} \sim \mathrm{C}_{4}$ 炭化水素の 合成に選択性の高い鉄のグラファイト層 間化合物触媒の活性低下と生成する炭化水素の分布に関する特 性を検討した。

触媒活性と生成する炭化水素分布の経時変化は，反応の時間 因子 (W/F)，すなわち $\mathrm{CO}$ 反応率の大きさに依存した。低反 応率領域 $(5 \%$ 以下) では触媒活性は反応時間とともに徐々に 減少し, ある一定の定常値を与えた (Fig. 1)。この活性低下に ともない, メタンに富えだ生成物分布に変化した。一方高反 忘率領域では，活性も選択性もほとんど経時変化しなかった (Fig. 2)。この両実験において反応系に打ける最も顕著な違い を, 生成する水蒸気の量と考え, 反応系への水蒸気の添加効果 を検討した。水蒸気を添加すると低反応率領域でも触媒活性の 低下が抑制され，生成物分布も高分子量炭化水素側に変化する

* 早稲田大学理工学部応用化学科（160 東京都新宿区大久保 3-4-1)
ことが認められた (Fig. 3)。さらに水蒸気添加を中止すると触 媒活性泜下し, この低下した活性は水素処理により再生され ることから, 活性低下の原因が炭素析出であることが明らかに なった (Fig. 4)。

また水蒸気を添加した場合および無添加の場合の動力学を検 討した結果, 水素に対する反応次数はいずれの場合も 0.9 次で あるのに対して, CO に関する次数は水蒸気の添加により 0.05 から 0.47 次に増加することがわかった (Figs. 7,8)。

これらの実験事実は, 低反応率領域では水蒸気の生成量が少 なく, 触媒活性の低下を生じ, 隣接活性点密度の低下により炭 素鎖成長が抑制されるため，メタンに富えだ生成物を与えると 考えることにより説明される。通常の鉄触媒に比べて，この鉄 の層間化合物触媒上での生成物分布が反応率に対して敏感なの は, この触媒固有の活性点密度の低いことに起因すると考元ら れる。

\section{Keywords}

Carbon monoxide, Graphite, Hydrocarbon synthesis, Hydrogenation, Iron catalyst, Lamellar compound 